\title{
ケイ光 $\mathrm{X}$ 線による鉣物中のジルコニウムの定量
}

(昭 和 41 年 7 月 12 日 受理)

$$
\text { 舟 阪 渡・安藤貞一・富田. 与志郎*1 }
$$

鉱物中のジルコニウムを迅速に定量するためにケイ光X線法を試み, 内部標準としてストロンチウムを用いる検量線法が適当で あることを認めた。すなわち，試料 $100 〜 500 \mathrm{mg}$ に炭酸ストロンチウム $100 \mathrm{mg}$ を加え，融剤としてフッ化水素ナトリウム $5 \mathrm{~g}$ 扣よびリン酸水装二ナトリウム $5 \mathrm{~g}$ を用い，さらに硫酸カリウム $5 \mathrm{~g}$ 添加して融解し，融成物について $\mathrm{Zr} K_{\alpha}\left(\mathrm{Sr} K_{\beta}\right.$ を含む） 执よび $\operatorname{Sr} K_{\alpha}$ の強度を測定し，標準酸化ジュニウムを用いて同様な処理によって得た検量線を使って定量値を求めた。Zr $K_{\alpha} に$ 対する $\mathrm{Th} L_{\beta}$ の重なりは. $I_{\mathrm{Th} L_{\beta}} / I_{\mathrm{Th} L_{\alpha}}=0.446$ を用いて $\mathrm{Th} L_{\alpha}$ により補正した。諸種の共存元素の影響はほとんどなく，模擬試料 ( 3 種) および実試料（2 種）について満足すべき結果が得られた。

\section{1 緒言}

ジルコニウムは天然にバデライト,ジルコンとして産出するが, このほか苗木石, 山口石などの変種ジルコンも存在し,これらは 希土類,トリウム, ウラン, ニオブ, タンタル, リン等をかなり 含んでいる。またりン酸希土鉱物中にジルコニウムが著量認めら れることもある。しかもジルコニウムはかならずごくわずかのハ フニウムを伴うので, このためジルコニウムの化学分析は一層や っかいなものになっている。

一方，ケイ光X線によるジルコニウムの定量に関してはすでに 若干の報告 ${ }^{1,2,3)}$ があるが，いずれも分析化学的に十分な検討を経 たものとは認め難く，ジルコニウム定量法として確立されたもの は存在しない。

そこで，著者らは，これらの種々の鉱物中のジルコニウムに対 する画一的な迅速分析法として，ストロンチウムを内部標準とす るケイ光X線法を試み， $\operatorname{Zr} K_{\alpha}$ に対してピークの重なりによる妨 害を与える $\mathrm{Th} L_{\beta}$ を $\mathrm{Th} L_{\alpha}$ から推定してとり除く方法を採用し たところ，共存元素を除去する操作を省いても好結果が得られた ので報告する。

\section{2 試薬および装置}

\section{$2 \cdot 1$ 試 薬}

標準酸化ジルコニウム：市販最純品（純度 $98 \%$ 以上）

炭酸ストロンチウム：特級硝酸ストロンチウム溶液と 1 級炭酸 アンモニウム溶液とを混合し, 生成する沈殿をネスラー試薬によ る呈色が認められなくなるまで洗浄してロ別し，110 $\mathrm{C} て ゙$ 乾燥し た。

$$
\text { フッ化水素ナトリウム: 特級品 }
$$$$
\text { リン酸水素二ナトリウム: 特級品 }
$$

硫酸カリウム：特級品

添加用試薬：特級品またはこれに準ずるもの

セリウム族希土酸化物：新日本金属化学(株)製

イットリウム族希上酸化物：JIS の方法()にしたがってゼノタ

*1 Wataru Funasaka, Teiichi Ando, Yoshiro Tomida 京都大学工学部工業化学教室: 京都市左京区吉田本町.

1) J. Hower, T. W. Fancher, Science, 125, 498 (1957).

2) D. A. Norton, Am. Mineralogist, 42, 492 (1957).

3) D. M. Mortimore, P.A. Romans, J. Opt. Soc. Am., 42, 673 (1952)

4) JIS M 8404, 鉱石中の希土類分析方法 (1963).

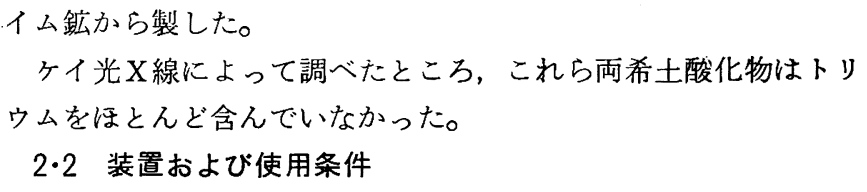

\section{3 実験および結果}

\section{1 検量線の作成}

白金ルッボに標準酸化ジルコニウム $0 ， 25 ， 50 ， 75$ または 100 $\mathrm{mg}$ と炭酸ストロンチウム (内部標準) $100 \mathrm{mg}$ をとり，融剤と してフッ化水素ナトリウム $5 \mathrm{~g}$ およびリン酸水素二ナトリウム $5 \mathrm{~g}$ を加え, さらに硫酸カリウム $5 \mathrm{~g}$ を添加してフタをし、はじ め徐々に加熱, 後に強熱して融解し, 融解完了後徐冷した。融解 の目的は試料と内部標準物質とを均一に混合すると同時に，希釈 によってマトリックス効果を減少させる点にある ${ }^{5,6)}$ 。融用とし てピ口硫酸カリウムを用いると, 融成物が不均質になりがちで, その後微粉䂗することが必要になるが，上記の融剤では高温では ぼ透明になるまで完全に融解され，均質な融塊となるようである （融解をくりかえしてもX線強度の比はほとんど変わらない）。フ

*2 $\mathrm{Zr} K_{\infty}$ 扰よび $\mathrm{Sr} K_{\alpha}$ に対する諸元素のピークの重なりを調 ベたところ， $\operatorname{Zr} K_{\infty}$ に対する $\operatorname{Sr} K_{\beta}$ および $\operatorname{Th} L_{\beta}$ の重な りのほかは認められなかった。

*3 含シルコニウム鉱物中に存在する程度の鉛では $\mathrm{Pb} L_{\beta}$ はほ とんぞ認められないが, 装置に起因する $\mathrm{Pb} L_{\boldsymbol{\beta}}$ の重なりを 避けて Th $L_{a}$ はピークの有で計測した。

*4 $\mathrm{Zr} K_{\infty}$ および $\mathrm{Sr} K_{\infty}$ に対しては 2 点の平均値を, $\mathrm{Th} L_{a}$ に 対してはこの平均値と $30.00^{\circ}(2 \theta)$ の值との平均値をそ れぞれバックグラウンドとした。

5) E. L. Gunn, Anal. Chem., 29, 184 (1957).

6) F. Claisse, Norelco Reptr., 4, 3 (1957). 
ッ化水素ナトリウムのみを用いた場合には, 高温でジルコニウム が沈下し，不均質化を招く傾向があったが，リン酸水素二ナトリ ウムを併用すると，この尔が克服されるばかりでなく，リン酸 水素二ナトリウムが泠却固化のさいに著しく収縮する性質をるつ ので, ルッボからの融塊のとりはずしがきわめて容易になる。硫 酸カリウムを添加したのは，融成物のX線吸收を大にして酸化ジ ルコニウム括よび炭酸ストロンチウムの科取量を増し, 科量䛊差 を減少させるためである。

徐冷後融塊をとり出し, こ れを図 1 のよ5に試料ホルダ 一に打さめ, 融塊の底面に ついて X 線強度比 $\left(I_{\mathrm{zr} K_{\alpha}}+\right.$ $\left.I_{\mathrm{Sr} K_{\beta}}\right) / I_{\mathrm{Sr} K_{\alpha}}$ を测定し，この 比を酸化ジルコニウムと炭酸 ストロンチウムとの重量比 $W_{\mathrm{ZrO}_{2}} / W_{\mathrm{SrCO}_{3}}$ に対してプロ ットして検量線を作成した。 得られた検量線を図 2 に示 5。

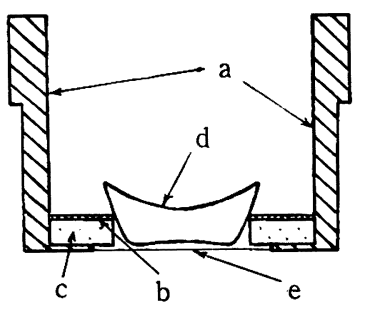

図 1 融塊の装着

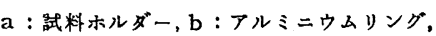
$\mathrm{c}:$ プラスチックリング, $\mathrm{d}$ ：融堍， e : マ イラー膜

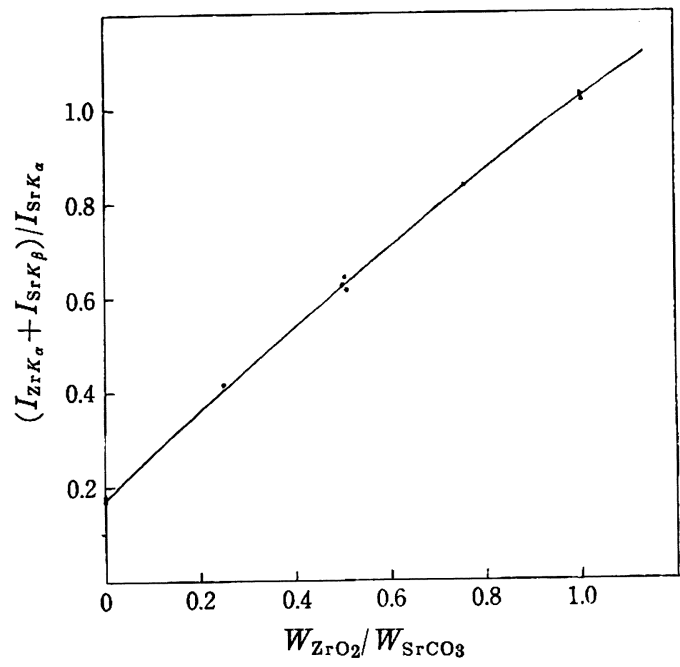

四 2 検 量 線

\section{$3 \cdot 2$ 共存元素（トリウムを除く）の影響}

上記の検量線が実試料の分析に利用できるかどうかの検討の第 一段階として，実試料中に存在することが予想される種々の元素 （ただしトリウムを除く）の影響について調べた。すなわち，白 金ルッボに炭酸ストロンチウム $100 \mathrm{mg}$ および添加試薬の一定量 をとり，これに酸化ジルコニウムを加えない場合 $\left(W_{\mathrm{ZrO}_{2}} / W_{\mathrm{SrCO}_{3}}\right.$ =0) 扣よび加えた場合 $\left(W_{\mathrm{ZrO}_{2}} / W_{\mathrm{SrCO}_{3}} \fallingdotseq 1\right)$ について $3 \cdot 1$ に記 した条件のもとで融解を行ない，得られた融塊について実測した $I_{\mathrm{Sr} K_{\beta}} / I_{\mathrm{Sr}_{\mathrm{K}} K_{\alpha}}$ または $\left(I_{\mathrm{Zr} K_{\alpha}}+I_{\mathrm{Sr} K_{\beta}}\right) / I_{\mathrm{Sr}_{\mathrm{r}} K_{\alpha}}$ を期待值（検量線に上っ

表 $1 I_{\mathrm{Sr} K_{\beta}} / I_{\mathrm{Sr} K_{\alpha}}$ に対する共存元素の影響a)（その 1 ）

\begin{tabular}{|c|c|c|c|c|}
\hline \multirow{2}{*}{\multicolumn{2}{|c|}{ 添 加 試 蔡 }} & \multicolumn{3}{|c|}{ 強 度 比 } \\
\hline & & 実测值 & 期 待 值 & 差 \\
\hline $\mathrm{SiO}_{2}$ & $100 \mathrm{mg}$ & 0.167 & 0.175 & -0.008 \\
\hline $\mathrm{Fe}_{2} \mathrm{O}_{3}$ & $40 \mathrm{mg}$ & 0.180 & " & +0.005 \\
\hline $\begin{array}{r}{[\mathrm{Ce}]_{2} \mathrm{O}_{3}} \\
+\mathrm{Ca}_{3}(\end{array}$ & $\begin{array}{l}100 \mathrm{mg} \\
\left(\mathrm{PO}_{4}\right)_{2} 100 \mathrm{mg}\end{array}$ & 0.168 & 11 & -0.007 \\
\hline$\left[\mathrm{Y}_{2} \mathrm{O}_{3}\right.$ & $100 \mathrm{mg}$ & 0.179 & "I & +0.004 \\
\hline $\mathrm{U}_{3} \mathrm{O}_{8}$ & $20 \mathrm{mg}$ & 0.176 & $" 1$ & +0.001 \\
\hline
\end{tabular}

表 $2\left(I_{\mathrm{Zr} K_{\alpha}}+I_{\mathrm{Sr} K_{\beta}}\right) / I_{\mathrm{Sr} K_{\alpha}}$ に対する共存元素の影響

\begin{tabular}{|c|c|c|c|c|c|c|}
\hline \multirow{2}{*}{ 添 加 訊 } & & \multirow{2}{*}{$\frac{W_{\mathrm{ZrO}_{2}}}{W_{\mathrm{SrCO}_{3}}}$} & \multicolumn{3}{|c|}{ 通i 度 此 } \\
\hline & & & & 央測值 & 期街做 & 差 \\
\hline $\mathrm{MgO}$ & & $\mathrm{mg}$ & 0.997 & 1.035 & 1.016 & +0.019 \\
\hline $\mathrm{Al}_{2} \mathrm{O}_{3}$ & & $"$ & 0.999 & 1.001 & 1.017 & -0.016 \\
\hline $\mathrm{SiO}_{2}$ & 100 & " & 1.003 & 1.015 & 1.020 & -0.005 \\
\hline $\mathrm{Ca}_{3}\left(\mathrm{PO}_{4}\right)_{2}$ & 100 & $"$ & 0.996 & 1.021 & 1.015 & +0.006 \\
\hline $\mathrm{Ti}$ & 40 & " & 1.001 & 1.037 & 1.019 & +0.018 \\
\hline $\mathrm{Mn}_{3} \mathrm{O}_{4}$ & 40 & " & 1.001 & 1.037 & 1.019 & +0.018 \\
\hline $\mathrm{Fe}_{2} \mathrm{O}_{3}$ & 40 & " & 1.001 & 1.033 & 1.019 & +0.014 \\
\hline $\mathrm{Nb}_{2} \mathrm{O}_{5}$ & 40 & " & 1.003 & 1.008 & 1.020 & -0.012 \\
\hline $\mathrm{SnCl}_{2} \cdot 2 \mathrm{H}_{2} \mathrm{O}$ & 80 & $"$ & 1.004 & 1.030 & 1.021 & +0.009 \\
\hline$[\mathrm{Ce}]_{2} \mathrm{O}_{3}$ & 100 & " & 0.999 & 1.042 & 1.017 & +0.025 \\
\hline$[\mathrm{Y}]_{2} \mathrm{O}_{3}$ & 100 & $"$ & 1.004 & 1.030 & 1.021 & +0.009 \\
\hline $\mathrm{Ta}_{2} \mathrm{O}_{5}$ & 40 & $" 1$ & 1.000 & 1.035 & 1.018 & +0.017 \\
\hline $\mathrm{Pb}\left(\mathrm{OAc}_{2}\right)_{3}^{\circ} \mathrm{H}_{2} \mathrm{O}$ & 5 & " & 1.003 & 1.014 & 1.020 & -0.006 \\
\hline $\mathrm{ThO}_{2}$ & 40 & " & 1.000 & 1.010 & 1.018 & -0.008 \\
\hline $\mathrm{U}_{3} \mathrm{O}_{8}$ & 20 & " & 1.002 & 1.017 & 1.020 & -0.003 \\
\hline
\end{tabular}

て $W_{\mathrm{ZrO} 2} / W_{\mathrm{SrCO} 3}$ から求める）と比較した。絬果は表 1 および 2 に示すとおりで，雨者の一致は良好であった。

\section{$3 \cdot 3$ トリウムの影響}

$\operatorname{Zr} K_{\alpha}$ および $\operatorname{Sr} K_{\beta}$ には $\operatorname{Th} L_{\beta}$ が重なるから，トリウムが共 存するときには当然との影響があらわれ，定量值には正の誤差が 伴 5ものと思われる。そこで実測される $\left(I_{\mathrm{Sr} K_{\beta}}+I_{\mathrm{Th} L_{\beta}}\right)$ または $\left(I_{\mathrm{Zr} K_{\alpha}}+I_{\mathrm{Sr} K_{\beta}}+I_{\mathrm{Th} L_{\beta}}\right)$ の中の $I_{\mathrm{Th} L_{\beta}}$ を $I_{\mathrm{Th} L_{\alpha}}$ から推定すること によってこの誤差を打ち消す方法を検討した。

まず酸化トリウム 20 または $40 \mathrm{mg}$ のみを $3 \cdot 1$ と同様な操作 によって融塊中にとかし込み， $I_{\mathrm{Th} L_{\beta}} / I_{\mathrm{Th} L_{\alpha}}$ を測定したところ，平 均值として 0.446 なる值を得た(表 3 )。そこで，炭酸ストロンチ ウム $100 \mathrm{mg}$ に酸化トリウム $40 \mathrm{mg}$ と種々の添加試薬の一定量 をむわせ加え，3.1 に記した条件のもとで融解を行ない， $22.50^{\circ}$ $(2 \theta)$ において実测される正味のピーク強度 $\left(I_{\mathrm{Sr} K_{\beta}}+I_{\mathrm{Th} L_{\beta}}\right)$ から $I_{\mathrm{Th} L_{\alpha}}$ の 0.446 倍をさし引いた值を真の $I_{\mathrm{Sr} K_{\beta}}$ とみなし，これと $I_{\mathrm{Sr} K_{\alpha}}$ との比を検量線から期待される值と比較した。結果を表 4 に示す。また，炭酸ストロンチウム $100 \mathrm{mg}$, 酸化ジルコニウム

$\left.\begin{array}{ccc}\multicolumn{5}{c}{\text { 表 } 3} & I_{\mathrm{Th} L_{\beta}} / I_{\mathrm{Th} L_{\alpha}} & \text { の測定 } \\ \mathrm{ThO}_{2} & 20 \mathrm{mg} & 0.445 \\ " 1 & 40 \mathrm{mg} & 0.446\end{array}\right\} \quad$ av. 0.446

表 $4 I_{\mathrm{Sr} K_{\beta}} / I_{\mathrm{Sr} K_{\alpha}}$ に対する共存元素の影響®（その 2 ）

\begin{tabular}{|c|c|c|c|c|c|}
\hline \multirow{2}{*}{ 添 } & \multirow{2}{*}{ 加 } & \multirow{2}{*}{ 蒋 } & \multicolumn{2}{|c|}{ 強 } & 此 \\
\hline & & & 实测 做 & 期 待 值 & 差 \\
\hline \multicolumn{3}{|c|}{$\mathrm{ThO}_{2} 40 \mathrm{mg}+\mathrm{SiO}_{2} 100 \mathrm{mg}$} & 0.172 & 0.175 & -0.003 \\
\hline " & \multicolumn{2}{|c|}{$+\mathrm{Fe}_{2} \mathrm{O}_{3} 40 \mathrm{mg}$} & 0.173 & "I & -0.002 \\
\hline$"$ & \multicolumn{2}{|c|}{$\begin{array}{l}+[\mathrm{Ce}]_{2} \mathrm{O}_{3} 100 \mathrm{mg} \\
+\mathrm{Ca}_{3}\left(\mathrm{PO}_{4}\right)_{2} 100 \mathrm{mg}\end{array}$} & 0.170 & $" 1$ & -0.005 \\
\hline " & \multicolumn{2}{|c|}{$+[\mathrm{Y}]_{2} \mathrm{O}_{3} 100 \mathrm{mg}$} & 0.176 & 11 & +0.001 \\
\hline$" \prime$ & \multicolumn{2}{|c|}{$+\mathrm{U}_{3} \mathrm{O}_{8} 20 \mathrm{mg}$} & 0.168 & $" \prime$ & -0.007 \\
\hline
\end{tabular}

a) $W_{\mathrm{ZrO}_{2}} / W_{\mathrm{SrCO}_{3}}=0$

$100 \mathrm{mg}$ および酸化トリウム $40 \mathrm{mg}$ をあわせとり，同様に融解処

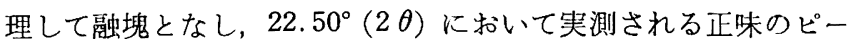
$\eta$ 強度 $\left(I_{\mathrm{Z}_{\mathrm{r}} K_{\alpha}}+I_{\mathrm{Sr}_{\mathrm{r}} \beta}+I_{\mathrm{Th} L_{\beta}}\right)$ から $I_{\mathrm{Th} L_{\alpha}}$ の0.446 倍をさし引い た值を真の $\left(I_{\mathrm{Zr}_{\mathrm{r}} K_{\alpha}}+I_{\mathrm{Sr} K_{\beta}}\right)$ とみなし，これと $I_{\mathrm{Sr} K_{\alpha}}$ との比を検 量線から期待される值と比較した。この結果は 3.2 の結果と対比 する意味から表 2 の中に記した。

これらの結果からみると,トリウムが共存する場合でも，上記 の方法による補正を施せば，他元素の共存のいかんにかかわらず， トリウムの影響を打ち消すことができるものと思われる。

3.4 模擬試料および実試料の分析

上述の検討結果は検量線（図 2) の両端に拈けるものであるか 
ら,この検量線は描かれた全濃度域にわたって適用可能であると 考えられる。そこで表 5 の No. 1，2 および 3 に示した組成(そ れぞれ苗木石，菊花石拉よびモナズ石に近い）をもつ模擬試料に ついて分析を試みた。

すなわち, 試料 100 ～ $500 \mathrm{mg}$ を 3.1 に記した条件のもとで融 解し，得られた融塊についてX楾強度を測定し， $22.50^{\circ} ， 25.16^{\circ}$ および $27.16^{\circ}(2 \theta)$ の強度からそれぞれのバックグラウンドを さし引いて，( $\left(I_{\mathrm{r}_{\mathrm{K} K} K_{\alpha}}+I_{\mathrm{Sr} K_{\beta}}+I_{\mathrm{Th} L_{\beta}}\right), I_{\mathrm{Sr}_{\mathrm{r}} K_{\alpha}}$ 扤よび $I_{\mathrm{Th} L_{\alpha}}$ を求め, さらに $\left(I_{\mathrm{Z}_{\mathrm{r} K_{\alpha}}}+I_{\mathrm{Sr} K_{\beta}}+I_{\mathrm{Th} L_{\beta}}\right)$ から $I_{\mathrm{Th} L_{\alpha}}$ の0.446 倍をさし引い て $\left(I_{\mathrm{Zr} K_{\alpha}}+I_{\mathrm{Sr} K_{\beta}}\right)$ を算出し, $\left(I_{\mathrm{Zr}_{\mathrm{r}}}+I_{\mathrm{Sr} K_{\beta}}\right) / I_{\mathrm{Sr} K_{\alpha}}$ から検量線を 用いて $W_{\mathrm{ZrO}_{2}} / W_{\mathrm{SrCO}_{3}}$ を推定し, これを $W_{\mathrm{sample}} / W_{\mathrm{SrCO}_{3}}$ で除 して試料中のジルコニウム含量（酸化ジルコニウムとして）を算 出した。結果は表 6 に示すとおりで，ほぼ満足すべきものであっ た。

ついで，実際の試料としてジルコンおよびモナズ石を上記の方

表 5 模擬試料の組成

\begin{tabular}{|c|c|c|c|c|c|}
\hline \multicolumn{2}{|c|}{ No. 1} & \multicolumn{2}{|c|}{ No. 2} & \multicolumn{2}{|c|}{ No. 3} \\
\hline $\mathrm{SiO}_{2}$ & $29.0 \%$ & $\mathrm{Al}_{2} \mathrm{O}_{3}$ & $0.5 \%$ & $\mathrm{Na}_{2} \mathrm{HPO}_{4}$ & $35.3 \%$ \\
\hline $\mathrm{Fe}_{2} \mathrm{O}_{3}$ & $1.7 "$ & $\mathrm{SiO}_{2}$ & $9.5 \prime \prime$ & $\mathrm{ZrO}_{2}$ & $11.8 "$ \\
\hline $\mathrm{ZrO}_{2}$ & $50.0 "$ & $\mathrm{CaCO}_{3}$ & $1.2 "$ & {$[\mathrm{Ce}]_{2} \mathrm{O}_{3}$} & $35.3 \prime \prime$ \\
\hline $\mathrm{Nb}_{2} \mathrm{O}_{5}$ & $2.3 "$ & $\mathrm{Na}_{2} \mathrm{HPO}_{4}$ & $36.1 "$ & $\mathrm{ThO}_{2}$ & $17.6 "$ \\
\hline$[\mathrm{Ce}]_{2} \mathrm{O}_{3}$ & $4.1 "$ & $\mathrm{Fe}_{2} \mathrm{O}_{3}$ & $0.5 \prime \prime$ & 計 & $100.0 "$ \\
\hline$[\mathrm{Y}]_{2} \mathrm{O}_{3}$ & $4.0 "$ & $\mathrm{ZrO}_{2}$ & $15.8 " \prime$ & & \\
\hline $\mathrm{Ta}_{2} \mathrm{O}_{5}$ & $2.4 \prime \prime$ & $\mathrm{Nb}_{2} \mathrm{O}_{5}$ & $0.5 \prime \prime$ & & \\
\hline $\mathrm{ThO}_{2}$ & $3.5 \prime \prime$ & {$[\mathrm{Ce}]_{2} \mathrm{O}_{3}$} & $15.9 "$ & & \\
\hline $\mathrm{U}_{3} \mathrm{O}_{8}$ & $3.0 "$ & {$[\mathrm{Y}]_{2} \mathrm{O}_{3}$} & $15.8 \prime \prime$ & & \\
\hline 計 & $100.0 "$ & $\mathrm{Ta}_{2} \mathrm{O}_{5}$ & $0.5 \prime \prime$ & & \\
\hline & & $\mathrm{U}_{3} \mathrm{O}_{8}$ & $3.7 "$ & & \\
\hline & & 計 & $100.0 " 1$ & & \\
\hline
\end{tabular}

表 6 模擬試料中のジルコニウムの定量

\begin{tabular}{|c|c|c|c|}
\hline & $\frac{W_{\text {sample }}}{W_{\text {srco }}}$ & $\underset{(\%)}{\mathrm{X}-\mathrm{Ray}} \mathrm{ZrO}_{2}$ & $\begin{array}{c}\text { 调製 } \mathrm{Z}_{(\%)} \mathrm{rO}_{2} \\
(\%)\end{array}$ \\
\hline No. 1 & $\begin{array}{l}0.996 \\
0.996 \\
0.998 \\
1.906 \\
1.932 \\
1.914\end{array}$ & $\left.\begin{array}{l}49.9 \\
51.3 \\
51.7 \\
50.2 \\
49.9 \\
49.5\end{array}\right\}$ & 50.0 \\
\hline No. 2 & $\begin{array}{l}2.513 \\
3.120 \\
3.810\end{array}$ & $\left.\begin{array}{l}15.9 \\
16.0 \\
15.9\end{array}\right\}$ & 15.8 \\
\hline No. 3 & $\begin{array}{l}1.695 \\
3.364 \\
5.068\end{array}$ & $\left.\begin{array}{l}11.4 \\
11: 1 \\
11: 3\end{array}\right\}$ av. 11.3 & 11.8 \\
\hline
\end{tabular}

表 7 実試料中のジルコニウムの定量

\begin{tabular}{|c|c|c|c|}
\hline & $\frac{W_{\text {sample }}}{W_{\text {SrCO}}}$ & $\underset{(\%)}{\mathrm{X}-\mathrm{Ray}} \mathrm{ZrO}_{2}$ & $\begin{array}{c}\text { Chem. } \\
\mathrm{ZrO}_{2}(\%)\end{array}$ \\
\hline ジルコン & $\begin{array}{l}0.497 \\
1.001 \\
1.503\end{array}$ & $\left.\begin{array}{l}68.0 \\
67.5 \\
66.9\end{array}\right\}$ & 66.61 \\
\hline モナズ石 & $\begin{array}{l}1.984 \\
2.487 \\
3.000\end{array}$ & $\left.\begin{array}{l}8.8 \\
9.6 \\
9.5\end{array}\right\}$ av. 9.3 & 9. 31 \\
\hline
\end{tabular}

法によって分析した。それぞれについて 3 回の実験値はよく一致 し，重量分析（ただし 0～2\% の酸化ハフニウムを含む）の值に も近かった。結果を表 7 に示す。

\section{4 考察}

ジルコニウムに対する内部標準としては, 吸収端の点だけから 考えると，ストロンチウムのほかにイットリウム，トリウムおよ びウランをあげることができるが，これら 3 元素は分析対象であ る鉱物中に含まれている場合があるので適当とはいい難い。これ に対して，ストロソチウムは，含ジルコニウム鉱物中にほとんど 含まれておらず，また $\mathrm{Zr} K_{\alpha}$ に対する $\mathrm{Sr} K_{\beta}$ の重なりも本報の 方法によればなんら障害にならないことが認められたので，内部 標準としてきわめて好都合なものである。

希土類，鉄，マンガン等の多量を添加すると融解中高温で不透 明な懸濁状態になるが，表 $1,2,4$ および 6 に示した実験結果か らみて，特に悪影響は生じていない。実際の試料の融解において も,これらの元素を含む場合には同様な状態になるはずであるが, この場合でも試料のもとの状態は完全に破壊され, 少なくともス トロンチウムおよびジルコニウムはガラス状に融けて，模擬試料 におけると同様の状態になるすのと考えられる。したがって，実 試料の分析值は十分真の值に近いものであろ5。

なお，重元素の著量の共存下ではX線の強度が減少するが，障 害は生じない。これは，内部標準法をとったため, マトリックス 変動が電源変動, 形状変動などとともに相殺されるからであろら。

(昭和 40 年 11 月, 第 3 回X線工業分析討論会で発表)

終りにのぞみ，本研究に御援助をいただいた新日本金属化学株 式会社西村新一博士に深く感謝する。 